\title{
Reading Categories Identified in the Reading Activities of a Caregiver and a Middle-Class Child
}

\author{
Borja-Alarcón Isabel $^{1}$, Ramirez Valencia Astrid ${ }^{1} \&$ López-Vega Alfonso ${ }^{1}$ \\ ${ }^{1}$ Faculty of Science and Education, Francisco José de Caldas Distrital University, Bogotá, Colombia \\ Correspondence: Ramirez Valencia Astrid, Faculty of Science and Education, Francisco José de Caldas Distrital \\ University, Bogotá, Colombia. Tel: 57-323-9300 Ext 3045. E-mail: astramirez@gmail.com
}

Received: September 4, 2017

Accepted: October 14, 2017 Online Published: October 16, 2017

doi: 10.5539/elt.v10n11p129

URL: http://doi.org/10.5539/elt.v10n11p129

\begin{abstract}
This paper aims to report the findings of a research project, developed from the need to make contributions about the characteristics that emerge, when a three-year-old child and his caregiver carry reading activities out. By the use of recordings and students' artifacts, in order to collect data; and analyzing the information collected through categorization, this case study revealed that both, the child and the caregiver, exposed reading attitudes and actions which have relationships with intake process, cognitive processes, emotional statements, autonomy, and the application of strategies to understand the text. In addition to this information, this study concluded that reading processes are complex and there is a considerable need to develop research around this topic.
\end{abstract}

Keywords: childcare, early childhood education, reading process

\section{Introduction}

National and international policies recognize early childcare as a need which requires attention, due to the importance of this stage of life, for individuals and societies. The UN (1948) included, into the human rights, the right to live, to be free and save. In addition, this organization highlighted the right to have a standard of living which benefits children and their families, in terms of health, food and education of quality. Moreover, the UN indicated that the objective of education shall be the full development of the human personality, and the development of respect towards fundamental human rights and freedoms.

The UN (1989) stated that "children have the right to acquire the benefits of social security, which implies special attention, before and after the mother's pregnancy." (p. 3). Furthermore, "children and their mothers must have attention, regarding health, food, recreation, housing and nourishment." (p. 7). Similarly, this organization points out children's right to free compulsory education, at least, in the elementary stages, and the fact that the child should receive education that "promotes his general culture." (p. 8). The child should have opportunities to have fun, aimed to learn. For its part, UNICEF (1989) agrees, among other children's rights, the following: 1) Non-discrimination; 2) The best interests of the child; 3) The right of life, survival and development; and 4) Respect for the child's opinions.

At the national level, the directions which address children's rights are the Republic Congress and the National Council for Social and Economic Policy (Conpes in Spanish).

The Law 1098, promulged by the Republic Congress (2006) states that early childhood is the stage in the life of the individual, whose core processes are cognitive, emotional and social development. Additionally, this paper defines early childhood as the period, between zero and six years of age, in which elementary education and nourishment are unavoidable rights.

For National Council for Social Economic policy Conpes (2007), the need to create an early childhood policy is based on considerations from many different fields:

- Science: The first years of life play a fundamental role in the development of each person.

- Legal Affairs and Politics: Colombia is a signatory to international agreements which recognize children's rights.

- Economics: There is a relationship between early childhood development and human development.

- Culture and Society: Early childhood is a stage of life which unfolds in a specific culture and social context. 
- Institutions and Programmes: There is a responsibility of assisting in early childhood development. Ethics: The creation of a public policy on children under the age of six, via a participatory process, must be seen as a priority.

\subsection{Early Childhood}

In scientific and Colombian legal documents, early childhood is defined as the period ranging from the birth to the age of six (Reyes, 2005).

Scientific papers show that physical, communicative, intellectual and social development is more intense in this stage of life (Zuluaga \& Giraldo, 2012).

Colombian discussions towards early childhood in the past decade, have promoted the participation of communities in the cultural appropriation of the importance of infancy, as well as the requirement for state institutions to make efforts, in order to solve families' and children's rights and to recognize kids as citizens with rights.

From 2003 to 2013, research studies have caused a better understanding of Colombian family; an illustration to create policies to achieve their goals. According to those studies, television sets the standard for many child-rearing practices, developed by caregivers, specially, members of the extended family (Varela, Chinchilla, \& Murat, 2015).

Orality, attachment, emotional bonds, autonomy, independence and confidence are phases of early childhood development, which can be recognized by specific clinical features, this, according to theorists. Stern (2005), however, considers them as components of the life's cycle, not only associated with infancy.

It seems that young children have an amodal perception, thanks to their perceptual system. This obtains information from one sensory modality, and transport it to another. This process is likely that infants perceive information in an unknown supramodal form, encoding it in an amodal representation which they recognize, and then, in any sensory modality. "Infants appear to experience a world of perceptual unity in which they can perceive amodal qualities in any modality from any form of expressive human behavior; represent those qualities abstractedly; and transpose them to any other modality" (Stern, 2005, p. 21). From this, one can assume that, thanks to their amodal perception, children read the world, before and after birth, and along infancy.

\subsection{Reading in Early Childhood}

Reading, as an activity of the psyche, occurs by a process of contacting three sources: 1) the book of intersubjectivity; 2) the book of the world; 3) the internal book. The first one involves a contact with the "book of others", where one might find the keys to share human experiences. The second refers to reading about the external world through the senses. And the third is the one which each person carries within himself (Cabrejo, 2003.). Reading is a process of dialogue and negotiation of meaning; an ongoing process which begins at birth (Reyes, 2005; Bruner, 1986).

There are two types of reading: The interpretative activity, which develops formal literacy, before birth to the first years of introduction to language, specially, in a family context. The other one is formal literacy, which implies that the child begins to read with others (Reyes, 2005).

Various authors, referring to the importance of reading, argue that:

- It allows us to recognize ourselves. Writers help us to give a name to our moods and feelings, to calm ourselves, to achieve a better understanding and sharing of them. Between the lines of stories written by others, we write our own. Writers reach each one of us as they concern themselves with deeply human experiences (Petit, 1999). For reading, it is necessary to enter the "textoteca" (the reading state or internal texts) (Devetach, 2008). Nietzsche (Zuleta, 1982) suggests that we can only read words in which we find something that we already know, generally, by experience; words which address, express and reflect upon our problems. In the case of reading young children, the child is the protagonist in the reading process. The objective of reading is to discover that texts contain many meanings and that everyone has to construct it "within himself." (Cabrejo, 2003).

- $\quad$ Reading provides an opportunity to see creative, fee and attentive children. Children read pictures and simple narratives represented by images; they are not submissive and passive learners. Babies pay attention to pictures in books because their eyes are drawn to them; they are also attentive to the voice that is reading and the facial expressions which accompany them (Blanco, n. d; Berger, Blomberg, Fox, Dibb and Hollis (2005). 
- Reading contributes to the motor, linguistic, emotional, cognitive and social development of the child. In addition, it helps to strengthen the bonds within the family and the community (National Council for Arts and Culture of Chile, n. d.; Lopez, 2007).

- Reading contributes to the achievement of early literacy. Reading illustrated books aloud is one of the practices with the greatest influence on early literacy, perhaps because of its nature as a routine and repetitive activity, the wide vocabulary offered by books, the opportunity the strengthen the relationship between children and adults, and for experiencing emotions (Goikoetxea \& Martinez, 2015).

- $\quad$ Reading stories promotes the development of values, according to an experimental study, which concluded that some teachers agree that literature transmit different values to children, according to their educational stage and the teacher's expertise (Marin \& Sanchez, 2015).

Regarding reading culture, some psycholinguistics and learning theories such as cognitivism and constructivism have found an influence of this process on language culture acquisition (Colomer, 2005).

The expected benefits of early literacy are expressed essentially in terms of future prospects and expansion of relationships. Early childhood reading is important because of its potential for enhancing emotional development and creating a "deep bond between mother and child which extends to the entire household", arising out of the positive attitude towards reading itself (Reyes, 2005), demonstrated by an excitement and interest from young learners towards reading, despite this process is in long term (Gallardo, Peralta, Lopez, \& Macias, 2013).

During the reading activity, children address complex stories which make them have relationships with people and events, in a distant and fictitious time, without being connected with academic issues aspirations for success (Reyes, 2005).

Children begin their reading process in the womb, listening to and storing their mother's voice in their psyche. After birth, the child interprets facial expressions, associated with visual contact; and later, he/she learns to read written texts (Cabrejo, 2003). As children come into contact with books, they construct meaning; the child recognizes the existence of a two-dimensional "other world" from illustrations mimicking reality, or in a dialogue in which child and adult simulate or act as if those illustrations were real (Bruner, 1986).

\subsection{Early Literacy Mediators}

The mediators, who are generally adults, contribute to reading processes in children in different ways:

- $\quad$ They connect the child and the book. (Reyes, 2011; Bruner, 1986).

- $\quad$ They give a sense of unity to the story (Reyes, 2011).

- They read and dramatize books. Up to the age of four, the mediator brings the child little collections of children's books, didactic materials and games (Deceano, 2013).

- They use facial and visual expressions. The attention provided by the child represents a later attitude towards reading books (Ministry of Culture, 2014). In the "love-triangle between adult, book and reader" construction of meaning takes place (Bruner, 1986).

- Mothers' full and regular participation, alongside teachers in work in the classroom, can help to invigorate reading processes (Mercado \& Montaño, 2015). Literacy practices developed by mothers and teachers have positive impact on the development of children's linguistic skills, no matter their differences (Rugerio \& Guevara, 2016).

- There are some recommendations for mediators contribute in the development of children's reading process. Allow the child to think for himself; be his companion in the process, and give him constant positive feedback (Cabrejo, 2003).

- Support children's reading processes; read to them before they know how to do so, in order that they see how it is done It is important to read anywhere, to buy and exchange books with children (Deceano, 2013).

- Introduce children to the world around them and to other universes while respecting their choices, and invite them to speak but respect their decisions by participating in silence (Gallardo, Peralta, Lopez, \& Macias, 2013).

- Centre the reading around children, paying attention to the bond being created with them, to their attitudes, expressions and desires, taking care not to impose on them but rather, listening to their suggestions and allowing to read the text in their own way (touching it, biting it, etc.) (Bogomolny, Faisal, Gasalla and Nejamkis, n. d.) 
- Read a variety of books to the child while it is still in the womb. After birth, get him used to constantly handling books of different materials and of different sizes in keeping with his age (Deceano, 2013).

- $\quad$ Read over several books with the child; rereading allows him/her to have further emotion and physical contact with the book (Devetach, 2008).

- During the reading, chat with the child about the characters and their experiences in the book (Bogomolny, Faisal, Gasalla and Nejamkis, n. d.).

- $\quad$ Offer the child a more complex variety of material, without being too rigid, and allow him to find his own pace (Blanco, s. d.).

- Appreciate the importance of asking questions as a tool for improving the child's cognitive level (Tornero, Truffello, Ramaccioti, \& Valenzuela, 2015).

- Develop continuous reading along the first four years of the child's life, aiming to develop, in him/her, the importance of practicing reading everyday. (Teyssedre \& Baudonniere, 2004).

In spite of the attention by mediators and the government, by implementing policies, in order that children get used to read literature, there is a "widespread realization" that this contribution is not as effective as expected. Moreover, there is a discussion about the functions of literature when having other reading media and, we must consider that current societies do not carry out the functions of learned societies but of "fully literate" ones.

Some studies paid attention to literacy development and selection of books. However, there is a need to research on reading procedures and the interrelation between book, mediator and reader. (Colomer, 2005).

Although Colombian policies early childhood and public education demonstrated the need to study on children's reading processes; activities such as the reading fair by Colombian Welfare Institute have been launched, in support of early childhood literacy; and the disappointing results obtained by elementary students in international tests such as PISA (Semana, 2014), there is still the need to conduct a study on the validity of these tests.

The main objective of this project was to contribute with knowledge about the characteristics raised from reading activities by a child and his caregiver.

\section{Methodology}

This qualitative intrinsic case study (Stake, 2007) was exploratory and descriptive in scope; this project does not have pretensions to frame generalizations. The population of this research is composed by a three-year-old child $(\mathrm{N})$, immersed into a real daily reading situation; and his 59-year-old grandmother (C), who plays the role as a caregiver. In addition, she is retired and has undergraduate and graduate studies in education.

The procedure of this study is framed by five phases:

1) Literature Review: In this phase, the researcher searched for theories and previous research studies on reading processes in children, as well as national and international documents about children care and introducing infants to reading.

2) Research Design: Inclusion of the research paradigm and method to be applied in this project. In addition, a search of the data collection instruments and the information that the researcher needs to collect, in order to conclude this study. Something important to highlight is that the $\mathrm{C}$ expressed her interest on participating in this project, through the provision of data.

3) Data Collection: The information was composed by audiovisual recordings and C's artifacts, collected in nine sessions along November, 2015. Through these materials, the $\mathrm{C}$ and the researcher identified four texts that N requested repeatedly: Una Caperucita Roja, Agujeros de la nariz, Costras y Guías and Los Simpson.

C's artifacts were four written accounts about the reading activities, considering them as reading from a book, resulting in a sort of activities from the text. Furthermore, these written accounts were compared with the audiovisual data, in order to find discrepancies. As some of them appeared in the comparison, $\mathrm{C}$ modified the written accounts, including important information for this research.

4) Data Analysis: Before organizing the data into categories, the researcher gathered the observations and removed the repetitions in the data instruments. And afterwards, the data was categorized, making clarifications about categories raised from $\mathrm{C}$, other categories raised from $\mathrm{N}$, and the others raised from both.

5) Drawing Conclusions: The researcher displayed the results obtained from this intervention and the conclusions from this project, as well as some topics for discussion.

Excerpts 1, 2 and 3 are pieces of information from C's accounts. It is important to remark that they generate 
non-repeated analysis, and some observations and results from the analysis appear in italics and in brackets.

\section{Excerpt 1: An account of the reading Una Caperucita Roja}

My son gave me a book album, Una Caperucita Roja, by Marjolaine Leray. I observed the book; I love book albums. I admired the lovely illustrations and the use of colour [Association C makes between the book and pleasure] red for Caperucita, black for the wolf; one noted that in the dialogues, when it was the wolf's turn to speak, the letters were written in black ink and, when it was Caperucita's turn, they were in red. I saw the innocent little girl fall into the hands of the wolf who placed her on a dining table. I listened to the dialogue where she was talking about physical features until she got telling the wolf what enormous teeth he had and he then menacingly uttered those terrible words which have reached us from time immemorial when the story was first told orally: "The better to eat you with!" Later, I noted the disdainful attitude of the little girl who, by precise words and gestures, made the wolf lose his self-confidence to such a degree that he would soon fall for the trick that led to his downfall in front of a little girl who sat watching him calmly; the same girl who, at the end of the story, all by herself and remembering what had happened, uttered the words, "What a fool." [Full prior reading by $C]$.

When the boy arrived, he decided to watch a children's programme on the computer; later, I showed him the book; he took it in his hands [Communicative transaction] and began turning the pages [N turns the pages].

I: Who's that? [C asks about an illustrated character; a rhetorical question]

He: The girl. [N responds verbally to the rhetorical question]

I: And this one?

He: The wolf. [N addresses prior knowledge about the characters]

I: (I left the book open on the first page, on the armchair) [C leaves the book where the boy can reach it] The little girl goes walking [C begins the reading], the wolf is watching her while moving its paw [C relates what the illustrations show] ( I stood in front of him, placed my hands on my waist, slightly towards the back, and moved my right foot : leaning on my heel, I raised the front part of my foot time and time again, making audible sounds by tapping my shoe against the floor, all the while keeping my eyes on the boy [C plays the part of a character] He grabbed her from behind (I grabbed the child from behind by his shirt) [ $N$ assigns a role to N]; by this time I was already the wolf and he was the little girl or Caperucita).

I get out of character; I locate the second page of the book by sight; the two adjacent pages of the book show a single event: the wolf grabbing the girl from behind by the shoulders and the girl shouting, "Hey!"

I: The girl said, "Hey! Say, "Hey!" [C reads what N's character says, and asks him to say it after her].

In theatrical performances, a prompter is sometimes used, hidden from the audience so that he can whisper an actor's lines to him

\section{He: Hey! [ $N$ assumes his role: he repeats what Caperucita is supposed to say].}

I get out of character; I turn another leaf of the book; the left and right pages each present a different event. With the book on the sofa, I use my index finger to show him what is happening on the left page. [C points out the spatial order of the text on the paper].

I: (having grabbed the child from behind again) Where're you going to, eh? [C makes different gestures and movements].

In a very soft voice, I say to him: “To my grandmother's house." [C changes her tone of voice, In order that $N$ identifies and understands wolf's and Caperucita's turns to speak]

He: To my grandmother's house [N plays his role; he repeats the words that he is supposed to say]

(...) I get out of character; I turn another leaf of the book: the adjacent left and right pages present a part of the dialogue; the wolf, facing slightly sideways and looking up, is raising his hands to his throat while his mouth is wide open and we see that there is something red in his throat (the sweet Caperucita gave him for his bad breath, which was why he could not eat her). The child, sitting on the edge of the dining-table, leaning forward with her feet resting on the upright part of the table, is staring calmly at him.

Dropping softly to the floor, I lie on my back, simulating the wolf's gestures. The boy does the same [N ruptures the proposition of the text].

I: Aaaagh!

He and I: Aaaaaaaaaaaaagh! [N ruptures the proposition of the text; $C$ accepts it] 
Caperucita was read on six other occasions, each time at the request of the boy [ $N$ and $C$ read the text several times]. Variations in the readings stemmed from the fact that, by N'S decision and C's acceptance, some parts about the wolf's character were left out although the part about the bad breath was always read so as to get to the part about the wolf's surprise and the trick that Caperucita plays on him $[N$ selects the parts he finds interesting, leaving out what he is not interested in reading].

Excerpt 2: Account of the reading Agujeros de la Nariz and Costras

Both show illustrations and words.

Browsing through a bookstore specializing in literature for children and young people, I came across Agujeros de la nariz and Costras, both by Genochiro Yagyu. The titles drew my attention; I liked the pictures and the simple way in which topics are explained and recommendations made to children; also the association between pictures and words and the use of everyday words. I bought the book [Association of pleasure between $C$ and the book].

I read them carefully in my apartment, then I placed them on the shelf of the bookcase. [Prior reading by C]

The child arrived and after we finished playing a game where he was drove a train and I was the passenger [Communicative transaction], I took three books and placed them on top of the armchair (El Globo, by Isol, Agujeros de la nariz and Costras) [C leaves the books where $N$ can reach them].

The first one he took up was Agujeros de la nariz; he began turning the pages [ $N$ starts reading]; he stopped on a page showing a boy sneezing while mucus comes out of both nostrils. He asks me what is happening to the boy [N asks a question]; I explain that dust had got into in his nose and it made him sneeze (I imitated the act of sneezing) [C responds, using words and gestures] and mucus came out of his nose.

After, he turned more pages until he came across the drawings of a naked boy and a naked girl on whose bodies several holes could be observed (nose, eyes, mouth, anus, ears); he stood looking at them [ $N$ observes the text (sketches and words)] and I showed them to him, reading out what was said in both drawings [C points out illustrations and words].

He closed the book [ $N$ brings the reading to an end].

This book was read in a similar manner on various occasions (a total of four more during the month previously mentioned) during which the child sometimes paid more attention to certain pages than to others; sometimes only to some pages; sometimes, no attention at all [ $N$ ruptures the proposition of the text; $C$ accepts it]

Afterwards, he read Costras. In the book, there is a picture of a mother telling her son, "Don't remove that scab.!" And there are several accidents which leave the boy with injuries that later turn into scabs, as well as graphic pictures of the boy looking at the scabs and touching a scab. The book explains what a scab is, in words and pictures.

During the reading, the child began turning the leaves of the book and looking at the illustrations [ $N$ initiates the reading], going through the pages and describing what he was seeing:

I: The boy fell off his bicycle. [While he reads, $C$ explains the pictures].

He: Nan, what happened to him? [N identifies the illustrations that he does not understand, and asks questions about them; rhetorical questions]

I: Look, Jake, the boy is going too fast on his bike and he scrapes his hand against a wall. Ouch! He's bleeding! [C responds, using exclamations for emphasis]

Excerpt 3: Account of the reading Guia completa de los Simpson

This book, 250 pages long, 20.7 by $23.7 \mathrm{~cm}$ high, with colour illustrations, was lying on the bookshelf; I was not very familiar with it; in fact, I had only seen some of its illustrations and read only part of it [C's lack of familiarity with the book].

One day when the boy arrived, he saw it and took it down; he then took it to the chair and put it down on it $[N$ decides which book to read; C agrees with the decision]

The boy began to turn the pages. He found an illustration of baby Bart in a diaper, with a pacifier. He said, "This boy is wearing a diaper." I told him that it was Bart Simpson in a diaper. Jake said, "and he has a pacifier." [N complements what the caregiver is reading].

He continued leafing through the book until, on two adjacent pages, he came across a drawing of a naked Homer with a chain around his neck; the chain was tied to a big stone which Homer was dragging. Both pages also have several text boxes, some with a colored background, and others with colored text frames and other drawings of 
different sizes; they are pages saturated with content just like the others in the book. Jake was fascinated by Homer's nakedness and began laughing.

He: He doesn't have any clothes! Nan, he has poop on him! [N recognizes and verbalizes a taboo subject]

And he laughed. [N begins laughing at the face of a subject considered as taboo]

I: Yes, Jake! Homer has poop on him! [C accepts the recognition and the verbalization of a taboo subject].

And I also laughed. [C follows N's lead and laughs at the face of a taboo subject]

[N ruptures the proposition of the text; $\mathrm{C}$ accepts it].

Further returns to this book involved $\mathrm{N}$ turning several pages at the same time, stopping in front of some pictures that drew his attention, observing them and asking, "Nan, what's happening here?" [N identifies illustrations that he does not understand]. One example of these pictures is an illustration where, on the left, Freddy Quimby is seen in a river with a light jacket and tie and, behind him, there are two stakes, each one of which has a rope going to the river. On the right-hand side of the illustration, Bart is looking at Mr. Quimby in astonishment. [N observes the illustrations and asks questions about what is happening in them]

Other illustrations which attracted the child's attention and made him inquire about what was happening in them were two with a yellow background. In both, the character depicted was a female medical doctor: one, showing the doctor with arms folded and mouth closed and, next to her, a large sign which reads," DO NOT EAT BEEF" ( each word in a separate line); the other showing the doctor sitting at the dining-table, knife and fork in hand, before a plate of meat, while on the wall behind her hangs the head of a deer and a large sign says "EAT DEER" (one word per line). [ $N$ and $C$ perceive similarities and differences in texts and illustrations with common features].

\section{Results and Discussions}

The analysis of this data allowed us to identify, in the N's reading activities accompanied by $\mathrm{C}$, the categories which are listed below, including an indication of the categories in common and isolated for $\mathrm{N}$ and $\mathrm{C}$.

\subsection{Categories Identified in the Child and the Caregiver}

1) Association of the text with pleasure.

2) Prior knowledge of text.

3) Communicative transaction.

4) Asking questions.

5) Expressing and responding by words and gestures.

6) Making possible, an access to the book.

7) Beginning the reading.

8) Describing what is shown in illustrations.

9) Playing a character's role.

10) Assigning a character's role.

11) Differentiate characters' roles by changing tone of voice.

12) Reading the same text several times.

13) Observing the text (drawings and pictures).

14) Pointing out illustrations.

15) Oral reading and description of illustrations.

16) Perceiving similarities and differences in illustrations and texts with common features.

17) Turning pages.

\subsection{Categories Identified in the Child}

1) Repeating his lines after being told what to say.

2) Rupturing the proposition of the text.

3) Deciding what book to read.

4) Omitting, during the reading, parts of the text that he is not interested in reading. 
5) Complementing what the others are reading.

6) Asking non-rhetorical questions.

7) Responding to rhetorical questions.

8) Recognizing taboo subjects.

9) Verbalizing taboo subjects.

10) Initiating laughter in the face of taboo subjects.

11) Identifying illustrations that he does not understand.

12) Asking what a particular illustration is depicting.

13) Bringing the reading to an end.

\subsection{Categories Identified in the Caregiver}

1) Reading what a character says.

2) Indicating that an expression be repeated after she says it.

3) Indicating the spatial order of the text on the paper.

4) Accepting the rupture of the proposition of the text.

5) Pointing out words.

6) Perceiving words.

7) Answering rhetorical questions.

8) Accepting recognition of taboo subjects.

9) Verbalizing taboo subjects.

10) Following N's lead and laughing at taboo subjects.

11) Agreeing to read the book selected by $\mathrm{N}$.

12) Agreeing to the omission of the parts that $\mathrm{N}$ is not interested in reading.

In these activities, the reading process between $\mathrm{N}$ and $\mathrm{C}$ took a form of.

1) Representation.

2) An information acquisition process from the book that could be applied to both readers' situations.

3) Provocation and justification of verbalizing of taboo processes (elimination of facial matter, getting into a state of nudity, emission of mucus). These forms were shaped by factors such as the socioeconomic context, the books selected for reading, the unfolding stories of the readers' lives, and the confidence between $\mathrm{N}$ and $\mathrm{C}$.

The reading activities, which entailed representing (reading) Caperucita and transposing its textual contents to the present, required $\mathrm{C}$ to perform a double role: the wolf's and the prompter's; the latter, considered as a figure associated with theatrical performances, who remained hidden so that he could whisper an actor's lines to him, undetected. Something interesting here is that the actors and the audience are the same (N and C); also, the fact that $\mathrm{N}$ would have been guilty of violating the textual order by playing a double role: Caperucita's and the wolf's; the latter, being a role he chose to play because it allowed him to participate in the crucial scene, making gestures and sounds. Based on this, we could argue that $\mathrm{N}$ recognized the moment of greatest danger, facing the wolf and wished to take part on it. However, his immediate recovery, which saw him getting to his feet and saying "What a fool" to the dying wolf, was a rupture of the proposition of the text, which showed Caperucita annoyed but not addressing the wolf; instead, saying aloud to herself, "What a fool", giving voice to her thought that "That wolf was a fool."

In the reading activities around the other books, a rupture of the proposition of the text arose from greater, less, or no attention, focused on particular pages of the books. As a general rule, propositions of the text place contents, one after another, in the spatial order, implied by the temporal order of events. In this case, the rupture of the proposition of the text appeared when $\mathrm{N}$ decided to focus his attention on pieces of text, especially, when there are pages full of text, resulting in a subsequent textual synthesis process. In these readings, the use of exclamations, by both $\mathrm{N}$ and $\mathrm{C}$, not only served to emphasize a particular detail in the text but also shifted the situation to the readers' actual time.

Reyes (2005) and Bruner (1986) conceived reading as a process of dialogue and negotiation of meaning. In the 
reading activities between $\mathrm{N}$ and $\mathrm{C}$, we could see reading as a complex process. In it, negotiation of meaning and dialogue took place between $\mathrm{N}$ and $\mathrm{C}$; the text is an element that makes dialogue and negotiation dynamic, as well as an element exposed to influence and transformation, in the sense that N's reading involves transformation procedures; in other words, each text gives rise to $\mathrm{N}$ and C's versions of it, thanks to the peculiar perceptual processes to each. The reading of the world in early childhood, which Stern (2005) refers to the possibility, even before birth, of reading oneself the others, is closely associated with what Cabrejo (2003) defines as the book of the self, the book of intersubjectivity and the book of the world.

If we accept Stern's theory, C's gestures were perceived and interpreted by $\mathrm{N}$ codes from the images and graphics in the text; an inverse operation was observed when $\mathrm{N}$ assumed his role in the representation from the oral text, into which the written and illustrated text had been transformed by $\mathrm{C}$.

Reyes's (2011) pointed out that the adult reader brings a sense of unity of message to the text, underscoring the fundamental nature of the latter's role in very early reading process, which is equivalent to saying that, without participation, the child would not perceive that books contain stories. Our experience in the development of this research shows that $\mathrm{N}$ expected each book to relate at least one narrative - which does happen -, $\mathrm{C}$ confirmed that expectation by giving an outline of the story, causing that $\mathrm{N}$ relates it by himself. This leads us to identify the instinctive motivation behind children in taking their first steps towards reading: to find stories, bearing in mind that children are fond of them. It also leads us to believe that Reyes's (2011) statement ought not to be taken as the definitive one on the matter, and that there is a need of research, aimed at pinpointing those stages of reading acquisition process, where the child is not capable of perceiving unity in the story, without the input of the adult reader.

Reyes (2011) maintains that, as children read, they become involved with increasingly complex stories, and come to understand that a particular event occurred at some distant time. Based on our analysis, we can say that, in the case of the child of this study, there was, first of all, a clearly fictional time and space which exist "inside the book", installed within its pages, so to speak. Another clear aspect was the sense that the fictional space could be transformed into a real space of the representation, and fictional characters could be 'brought forward' to the actual time of the representation, framed differently and, with different physical characteristics, but remaining themselves. This transposition, supported by $\mathrm{C}$, allowed $\mathrm{N}$ take part in this game of 'make-believe' which, according to Bruner (1986), is where there is a foundation around the development of symbolic thinking.

If reading means interpreting the world, then every moment of this experience are important for developing this skill.

$\mathrm{N}$ distinguished between books relating fictitious events, and those ones which contained scientific information. His attitude towards the first tended to be more playful, whereas his attitude towards the latter was more oriented to an interest of learning. Similarly, he was able to differentiate between representable books, such as Una Caperucita Roja and those which were non-representable. The difference, however, was not related to whether they told a story or not. In the case of the non-representable book Guia Completa de los Simpson, he would ask "What happened?" and "Why?" just as he did in the case of Agujeros de la Nariz and Costras. If we speak strictly in terms of the design characteristics of the books involved in the reading activities, the difference between the representable and non-representable ones rely on the fact that the former are smaller in size, has fewer pages and characters, and deal with a single event. In the case of Una Caperucita Roja and El Globo, the form of reading proposed by $\mathrm{C}$ since the very beginning, was the form of representation.

Furthermore, the analysis showed that $\mathrm{N}$ is an assertive reader, in the sense that, although he allowed $\mathrm{C}$ to participate in the reading activity, he did not always allow her to turn the pages and he chose the books. He only allowed her to turn the pages of the represented texts, perhaps because he was busy, trying to get into his role; he asked questions and complemented C's responses; he also gave responses and ruptured the proposition of the text.

As a companion in the reading, $\mathrm{C}$ adapted her actions, in order to fit those that $\mathrm{N}$ did not attempt to take the lead role from him. Additionally, she enjoyed the reading and made it possible for $\mathrm{N}$ to follow his own path.

\section{Conclusions}

Several international organizations have designed and implemented policies, based on the concern that it is necessary to establish conditions to achieve the best early childhood development, considered as a core stage of life. Colombia has declared this stage of life as a priority concern. Nonetheless, there are educational disparities which affect the quality of attention which children receive from parents and caregivers. The case object of this study has shown that a high-educated individual like $\mathrm{C}$ can provide a companionship in the reading process, 
which provide advantages, not only for N's self-expression, but for her own learning process.

The characteristics of N's reading activities (referred as categories in the analysis), with the company of C, which have been identified along the analysis of the data, revealed that the majority of those were common to both $\mathrm{N}$ and $\mathrm{C}$, involving a relationship with the book, interlocutory skills, representation and elaboration of stories; the ability to omit parts of the text without losing its essence, the ability to express orally what illustrations depict, and the ability to appreciate similarities and differences in illustrations and texts.

The characteristics identified, with regard to N's participation concerned repeating after being instructed to say something, which demonstrated his ability to recognize instructions; rupture of the proposition of the text; selecting the book to be read; and asking questions and complementing what the caregiver was reading. By these actions, $\mathrm{N}$ expressed initiative and autonomy. At the same time, he subjected himself - whether intuitively, out of ignorance or out of habit - to the social norm, requiring children to answer rhetorical questions while refraining from asking themselves, but he also violated social conventions which were illustrated on verbalizing taboo subjects and laughing in them.

C'participation showed attitudes of a person who enjoys and shares reading. The researcher could find that $\mathrm{C}$ is resourceful, in terms of suggesting texts, and accepts N's suggestions

In addition, the results allow us to recognize the complexity of reading processes; the variety of skills that the readers possess; and the need to continue conducting research, uninfluenced by people who would discredit reading processes and mediators, on the basis of quantitative reading tests, which fail in the acknowledgement of skills, information which is not possible to identify through quantitative methods.

With regard to the data collection method, the results showed that the video-recordings and C's written accounts were the necessary and appropriate for achieving the objective of the project. The author of this article wishes to emphasize how important it was for $\mathrm{C}$ to be the person who provided the data on the activities, for the video-tapes to provide confirmation of data presented in the reports, for the confirmation of the development of the collection, between $\mathrm{C}$ and the author of this research report, and for the analysis completed on a sample of C's adjusted artifacts, all in tune with the design characteristics of the research, its type and its scope.

\section{References}

Berger, J., Blomberg, S., Fox, C., Dibb, M., \& Hollis, R. (2005). Modos de Ver [Trad.]. (2nd ed). Barcelona: Gustavo Gili.

Blanco, L. (n. d.). Leer con Bebés. Cantos y Cuentos en el Jardín Maternal. Buenos Aires: Secretaría de Educación. Retrieved from http://www.buenosaires.gob.ar/areas/educacion/cepa/leer_con_bebes.pdf

Bogomolny, M., Faisal, D., Gasalla, A., \& Nejamkis, G. (n. d.). Primerísimos Lectores Argentina: Programa Nacional de Desarrollo Infantil. http://www.primerosanios.gob.ar/descargas/publicaciones/material-facilitadores/primerisimos.pdf

Brunner, J. (1986). El Habla del Niño. Barcelona: Paidós.

Cabrejo, E. (2003). La Lectura Comienza Antes de los Textos Escritos. Nuevas Hojas de Lectura. Bogotá: Fundalectura. Retrieved from http://www.cobdc.net/12JCD/wp-content/materials/SALA_E/CABREJO_lectura_comienza.pdf

Congreso de la República (2006). Ley 1008 [Governmental document]. Colombia. Retrieved from http://www.oas.org/dil/esp/ley_1008_de_2006_colombia.pdf

Consejo Nacional de Política Económica Social - Conpes (2007). Política Pública Nacional de Primera Infancia: Colombia por la Primera Infancia. Colombia: Conpes Social. Retrieved from http://www.mineducacion.gov.co/1759/articles-177832_archivo_pdf_Conpes_109.pdf

Colombia. Ministerio de Cultura. (2014). Lectura, Libro y Bibliotecas. Derechos y Orientaciones Culturales Para la Primera Infancia. Colombia. Retrieved from http://www.mincultura.gov.co/areas/artes/primera-infancia/publicaciones/Documents/Lectura,\%20libro\%20 y\%20bibliotecas\%20interactivo.pdf

Colomer, T. (2005). El Papel de la Mediación en la Formación de Lectores. Buenos Aires: FCE. Lecturas sobre lecturas 3. Retrieved from $\mathrm{http} / / /$ cerlalc.org/curso_didactica/doc/m3_c1/El_papel_de_la_mediacion_en_la_formacion_de_lectores.pdf

Congreso de Colombia (2006). Código de la Infancia y la Adolescencia. Retrieved from http://www.alcaldiabogota.gov.co/sisjur/normas/Norma1.jsp?i=38664\#36 
Deceano, S. (2013). Fomento de Lectura en Familia: Testimonio de Logro con un Hijo, Apasionado Lector. $I V$ Foro Iberoamericano de Literacidad y Aprendizaje. Pp. 367-374. Puebla: Consejo Puebla de Lectura.

Devetach, L. (2008). La construcción del Camino Lector. Argentina: Comunicarte

Gallardo, P., Peralta, M., López, G., \& Macías, V. (2013). Entornos de Lectura en la Primera Infancia: La Familia, la Biblioteca Pública y la Escuela. IV Foro Iberoamericano de Literacidad y Aprendizaje, 399-406. Puebla: Consejo Puebla de Lectura.

Goikoetxea, E., \& Martínez, N. (2015). Los Beneficios de la Lectura Compartida de Libros: Breve Revisión. Educación XXI, 18(1), 303-323.

Groening, M. (1998). Guía Completa de los Simpson. Barcelona: ediciones B. S. A.

Instituto Colombiano de Bienestar Familiar (n. d.). Fiesta de la Lectura. Retrieved from http://www.icbf.gov.co/portal/page/portal/PrimeraInfanciaICBF/Fiesta

Isol (1995). El Globo. México: Fondo de Cultura Económica.

Leray, M. (2009). Una Caperucita Roja. México: Océano.

Marin, V., \& Sanchez, C. (2015). Formación en Valores y Cuentos Tradicionales en la Etapa de Educación Infantil. Revista Latinoamericana de Ciencias Sociales, Niñez y Juventud, 13(2), 1093-1106.

Mercado, R., \& Montaño, L. (2015). Procesos de Participación Entre Profesoras de Jardines de Niños y Madres de Familia en Actividades de Enseñanza. Revista Mexicana de Investigación Educativa, 20, 347-368.

United Nations Organization. (1989). Convención Sobre los Derechos de los Niños. Retrieved from http://www.un.org/es/events/childrenday/pdf/derechos.pdf

United Nations Organization. (1948). Declaración Universal de los Derechos Humanos. Retrieved from http://www.un.org/es/documents/udhr/

Petit, M. (1999) Nuevos Acercamientos a los Jóvenes y la Lectura. Mexico: Fondo de Cultura Económica

Reyes, Y. (2003). Lectura en la Primera Infancia. Cuando Leer es Mucho Más que Hacer Tareas. Retrieved from https://issuu.com/bibliotecaaleer/docs/cuando_leer_es_mucho_m_s_que_hacer

Reyes, Y. (2011). La Literatura Infantil Desde Antes de la Cuna: Yo no Leo, Alguien me Lee, me Descifra y Escribe en Mí. México: Conaculta.

Reyes, Y. (2005). La Lectura en la Primera Infancia. Centro Regional para el Fomento del Libro en América Latina y el Caribe - CERLALC. Retrieved from www.oei.es/inicial/articulos/lectura_primera_infancia.pdf

Rugerio, J., \& Guevara, Y. (2016). Prácticas Alfabetizadoras de Madres y Profesoras: Sus Efectos Sobre Habilidades de Niños Preescolares. Revista Mexicana de Investigación Educativa, 21(68), 191-220.

Semana. (2014). Colombia, en el Último Lugar de las Pruebas de Educación. Colombia Quedó de 61 de 65 Países al ser Evaluado en Lectura y Matemáticas [Newspaper article]. Retrieved from http://www.semana.com/nacion/articulo/colombia-en-el-ultimo-lugar-de-las-pruebas-pisa/382250-3

Stake, R. (2007). Investigación con Estudio de Casos [Trad.]. (4th edition). Madrid: Morata.

Stern, D. (2005). El Mundo Interpersonal del Infante. Una perspectiva Desde el Psicoanálisis y la Psicología Evolutiva. Buenos Aires: Paidós.

Teyssedre, C., \& Baudonniere, P. (2004). Aprender de 0 a 4 Años. México: Siglo Veintiuno.

Unicef. (2002). Derechos de la Infancia. La Convención sobre los Derechos del Niño. Retrieved from http://www.unicef.org/spanish/specialsession/rights/

Tornero B., Ramaciotti, A., Truffello, A., \& Valenzuela, F. (2015). Nivel Cognitivo de las Preguntas que Formulan las Educadoras de Párvulos. Educar y Educar, 18(2), 261-283. https://doi.org/10.5294/edu.2015.18.2.5

Varela, S., Chinchilla, T., \& Murat, V. (2015). Prácticas de Crianza en Niños y Niñas Menores de 6 Años en Colombia. Zona Próxima, (22).

Yagyu, G. (1981) Agujeros en la Nariz [Trad.]. Valencia: Media Vaca

Yagyu, G. (1997) Costras [Trad.]. Valencia: Media Vaca

Zuleta, E. (1982). Sobre la Lectura. Retrieved from http://www.mineducacion.gov.co/cvn/1665/articles-99018_archivo_pdf.pdf 
Zuluaga, S., \& Giraldo, Y. (2012). Tengo Palabras para Nombrarte y Amarte. Revista Iberoamericana de Educación, 59(4), 1-9.

\section{Copyrights}

Copyright for this article is retained by the author(s), with first publication rights granted to the journal.

This is an open-access article distributed under the terms and conditions of the Creative Commons Attribution license (http://creativecommons.org/licenses/by/4.0/). 